\title{
Amniotic fluid from healthy term pregnancies does not harbor a detectable microbial community
}

\author{
Efrem S. Lim ${ }^{1,2}$, Cynthia Rodriguez ${ }^{3}$ and Lori R. Holtz $3^{3 *}$
}

\begin{abstract}
Recent studies have conflicting data regarding the presence of intra-amniotic microbiota. Viral communities are increasingly recognized as important although overlooked components of the human microbiota. It is unknown if the developing fetus is exposed to a community of viruses (virome). Given the debate over the existence of an intraamniotic microbial community and the importance of understanding how the infant gut is populated, we characterized the virome and bacterial microbiota of amniotic fluid from 24 uncomplicated term pregnancies using next-generation sequencing methods. Contrary to expectations, the bacterial microbiota of amniotic fluid was indistinguishable from contamination controls. Viral reads were sparse in the amniotic fluid, and we found no evidence of a core viral community across samples.
\end{abstract}

Keywords: Amniotic fluid, Microbiome, Virome, Sterile body fluid, Virus, Bacteria, Microbial invasion of the amniotic cavity

\section{Introduction}

Microbial communities play an important role early in the life of infant development by influencing nutritional and immune functions [1]. Because factors that influence the composition of the early gut microbiota have significant prognostic and therapeutic implications, there is intense interest in understanding if microbial interactions occur within the fetal environment and, if so, how they impact maternal and fetal health.

Amniotic fluid has traditionally been viewed as a sterile site [2]. In healthy pregnancies, culture-based studies of mid-trimester amniotic fluid obtained for genetic testing have either found amniotic fluid to be sterile [3-5] or only isolated bacteria in up to $13 \%$ of amniotic fluid samples [2, 6-8]. Similarly, targeted and broad range molecular methods to detect bacterial agents in mid-trimester amniotic fluid also either did not detect bacteria [9] or detected bacteria in only up to $11 \%$ of samples [10, 11]. However, bacteria can be detected in amniotic fluid from pregnancies with complications such as preterm labor [12],

\footnotetext{
* Correspondence: loriholtz@wustl.edu

${ }^{3}$ Department of Pediatrics, Washington University School of Medicine, $660 \mathrm{~S}$.

Euclid Ave., Campus Box 8208, St. Louis, MO 63110, USA

Full list of author information is available at the end of the article
}

preeclampsia [13], small for gestational age [14], and preterm prelabor rupture of membranes [15] by culture- and molecular-based methods. Recently, using next-generation sequencing, bacterial sequences were detected in amniotic fluid from 15 healthy term gestations [16], suggesting that human amniotic fluid harbors a microbial community. The detection of microbial populations in healthy term amniotic fluid implies that neonatal microbial colonization, and thus microbial influences on infant health and development, begins prior to birth.

Likewise, there is contention about the existence of bacterial populations in other components of the in utero environment including the placenta, cord blood, and meconium $[17,18]$. Bacteria have been isolated by culture [19] and visualized [20] in $21-26 \%$ of placentas from healthy term deliveries. Viable bacteria (Enterococcus, Streptococcus, Staphylococcus, or Propionibacterium) have also been isolated from the cord blood of healthy newborns [21]. With the advent of nextgeneration sequencing, bacterial sequences have also been detected in the placenta $[16,22]$ and meconium $[16,23,24]$ from term gestations. However, a recent study found that the bacterial microbiota of term placentas resembled that of contamination and extraction

(C) The Author(s). 2018 Open Access This article is distributed under the terms of the Creative Commons Attribution 4.0 International License (http://creativecommons.org/licenses/by/4.0/), which permits unrestricted use, distribution, and 
controls [25]. Furthermore, since gnotobiotic animals from many mammalian species can reliably be derived via sterile cesarean section, it is reasoned the in utero environment of healthy pregnancies is sterile [17].

Considerably less is known about viruses in the fetal environment. Specific pathogenic viruses such as cytomegalovirus (CMV), HIV, enteroviruses, influenza, rubella, varicella, Zika, and human papilloma viruses (HPV) are certainly transmitted transplacentally or vaginally to the fetus. Using targeted PCR, CMV, adenovirus, herpes simplex virus, human herpesvirus 6, enterovirus, Epstein-Barr virus, respiratory syncytial virus, and human parvovirus B19 can be detected in amniotic fluid obtained via amniocentesis for genetic screening [2630], apparently co-existing with the fetus without causing symptoms. Viruses are infrequently detected in amniotic fluid from a variety of disease states using PCR for a panel of eukaryotic viruses followed by mass spectrometry (PCR/ESI-MS) including $1.4 \%$ of amniotic fluid from women with preterm labor and intact membranes [31], 1.7\% of amniotic fluid from cases of preterm prelabor rupture of membranes [32], and 3\% of samples from women with sonographic short cervix [33]. Additionally, early in life stools (first $96 \mathrm{~h}$ of life) from term infants have both eukaryotic viruses and bacteriophage present [34]. However, there are no studies using an unbiased approach to determine if viruses are present in amniotic fluid.

Here, we ask using sequence-based methods if term gestations have an amniotic fluid bacterial community and/or virome (community of eukaryotic viruses and bacteriophages), which would have major implications on our understanding of how the infant gut is initially populated by microbes.

\section{Results}

\section{Amniotic fluid has low bacterial biomass}

We evaluated 24 amniotic fluid specimens from term uncomplicated pregnancies obtained at the time of elective cesarean section at Barnes-Jewish Hospital, St. Louis, Missouri. The median maternal age was 28 years, and the median infant weight at birth was $3288 \mathrm{~g}$ (Additional file 1: Table S1 and Additional file 2).

To quantify the bacterial biomass in amniotic fluid specimens, we performed a GPCR assay to measure the absolute number of $16 \mathrm{~S}$ rRNA gene copies. The mean $16 \mathrm{~S}$ rRNA gene copies in amniotic fluid samples were 944 copies/mL (SD 374), a very low bacterial biomass (Fig. 1) when compared to pediatric stool samples which was $3.92 \times 10^{8}$ copies/g (SD $\left.3.84 \times 10^{8}\right)$. We were concerned that these low-density sequences reflected contamination. Therefore, we sought the $16 \mathrm{~S}$ rRNA gene copies in negative controls that were performed in parallel: DNA-free water (reagent negative control) that had

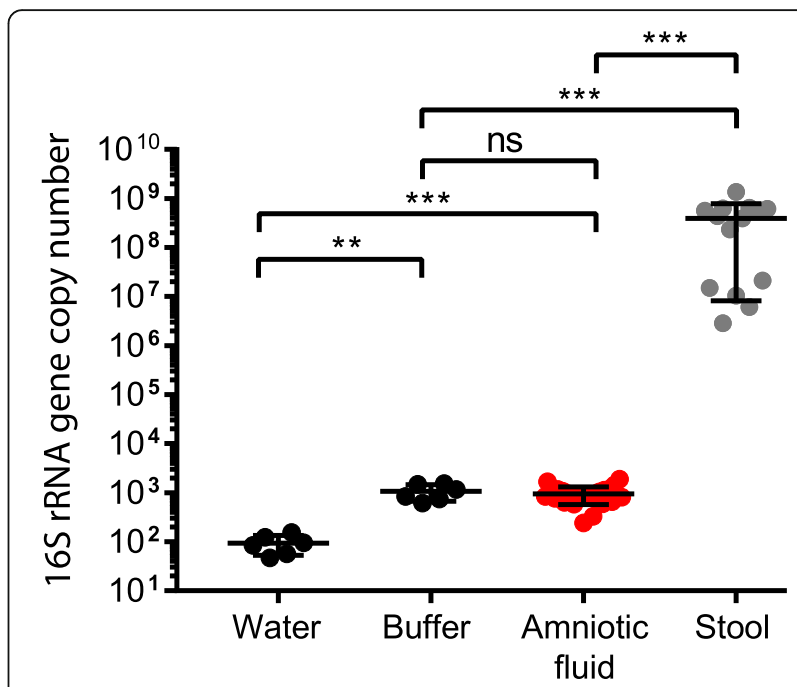

Fig. 1 Bacterial 16S rRNA gene quantitative PCR. 16S rRNA gene copies per reaction were quantified in the amniotic fluid samples, water (reagent negative control), buffer (extraction negative control), and pediatric stool samples. Statistical significance was assessed by Mann-Whitney test; ${ }^{*} P \leq 0.01,{ }^{* *} P \leq 0.0001$. ns, non-significant

no additional input material and did not undergo the DNA extraction protocol and extraction buffer that was subjected to the same DNA extraction protocol used for the samples (extraction negative control). The mean 16S rRNA gene copies in water (negative control) were 93 copies (SD 40), and the mean 16S rRNA gene copies in buffer extraction negative controls were 1062 copies/mL (SD 390). While amniotic fluid 16S rRNA gene copies were higher than the water negative controls, there was no statistically significant difference between the $16 \mathrm{~S}$ rRNA gene copy number between amniotic fluid and buffer extraction negative controls. Thus, consistent with prior studies [9-11], amniotic fluid had an absolute $16 \mathrm{~S}$ rRNA gene copy number indistinguishable from the extraction negative controls.

\section{The bacterial microbiota signature of amniotic fluid is indistinguishable from controls}

We next considered the possibility that amniotic fluid harbored a qualitatively different set of bacterial DNA than the reagents, i.e., that there was discrete bacterial microbiota present at low abundance in amniotic fluid. If so, bacteria of true amniotic fluid origin should differ in content from the negative controls. Therefore, we performed deep sequencing of the 16S rRNA gene V4 region from amniotic fluid, water (reagent negative control), buffer (extraction negative control), and pediatric stool samples (positive control) Additional file 3. Seven samples were omitted from further analyses as they contained less than $500016 \mathrm{~S}$ rRNA gene sequencing reads (five amniotic fluids, one water, and one buffer). We found that there was no statistically significant difference between the bacterial richness of 
amniotic fluid specimens and buffer extraction negative control (Fig. 2a). Amniotic fluid bacterial richness was higher than water negative controls, but lower than the stool controls. To compare the bacterial community structure between the amniotic fluid specimens and controls, we measured the unweighted UniFrac distances between
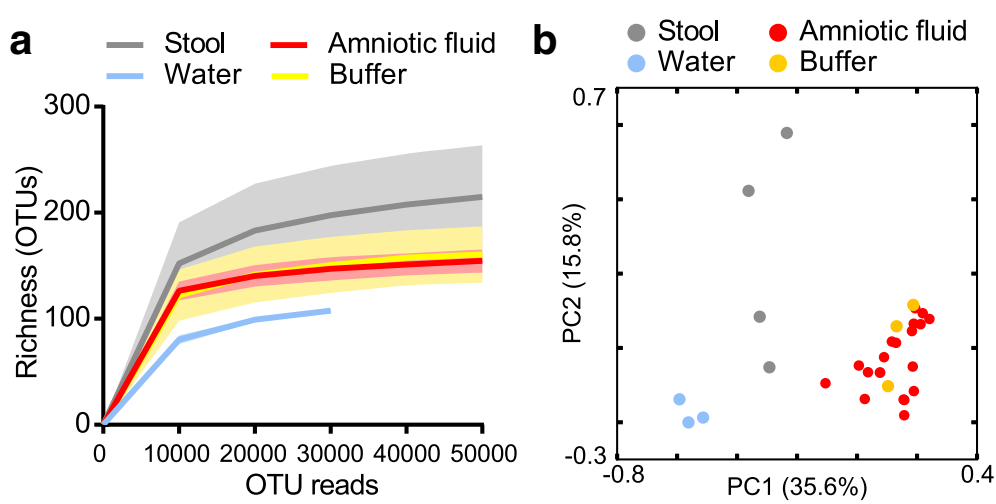

C

n.s.

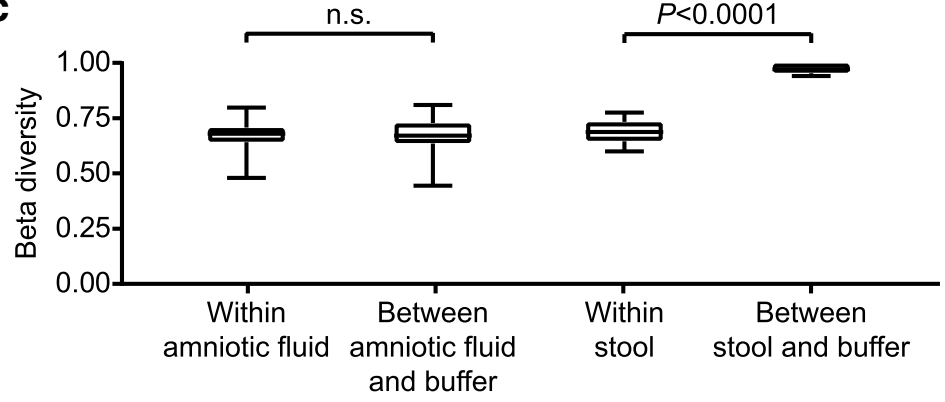

d
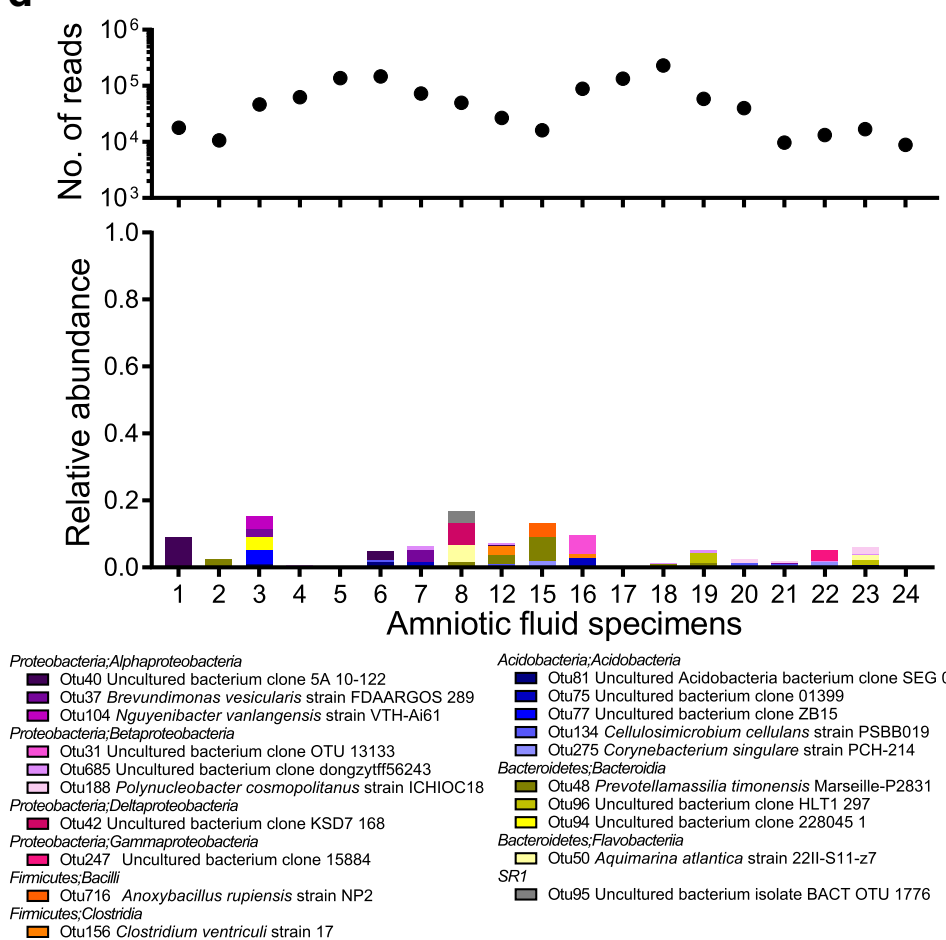

Acidobactenia

作 Acidobacteria bacterium clone SEG 08064

Otu75 Uncultured bacterium clone 0139

Otu134 Coltured bacterium clone ZB15 Otu275 Celulosimicrobium cellulans strain PSBB019 Bacteroidetes;Bacteroidia

(imonensis Marseille-P2831 Otu96 Uncultured bacterium clone HLT1 297 Otu94 Uncultured bact

Otu50 Aquimarina atlantica stran

Otu95 Uncultured bacterium isolate BACT OTU 1776

Fig. 2 The bacterial microbiota of amniotic fluid is indistinguishable from controls. a Richness (number of bacterial OTUs) of each sample type by sequencing depth. $\mathbf{b}$ PCoA of unweighted UniFrac distances. c Bray-Curtis dissimilarity analysis compared within sample type and between sample type and buffer control. Statistical significance was assessed by Mann-Whitney test. $\mathbf{d}$ Relative abundance of bacterial OTUs unique to amniotic fluid and not present in negative controls 
the samples and performed PCoA analyses. Amniotic fluid specimens overlapped extensively with buffer extraction negative controls but were distinct from stool (positive controls) and water negative controls (Fig. 2b). This was confirmed by Bray-Curtis dissimilarity analyses: although the bacterial microbiota of stool had significantly higher dissimilarities from buffer controls than when compared to other stools (Fig. 2c, right), we found no statistically significant difference between the bacterial microbiota detected in amniotic fluid and buffer controls (Fig. 2c, left).

We were concerned that a limitation of diversity measurements (Fig. 2b, c) is their lack of sensitivity for rare taxa, such as rare OTUs within a dominant background of contamination-derived OTUs. Therefore, we sought to identify bacterial OTUs that were present in amniotic fluid but absent from buffer and water negative controls Additional file 4. We found that bacterial OTUs unique to amniotic fluid accounted for very little of the relative abundance (Fig. 2d). Importantly, these rare bacterial OTUs were not frequently detected across the other amniotic fluid specimens.

\section{Viruses are rarely detected in amniotic fluid}

The emerging "intra-amniotic microbiome" hypothesis raises the possibility that amniotic fluid might also harbor a resident community of viruses. Thus, we investigated the virome of these amniotic fluid specimens. To comprehensively detect both DNA and RNA viruses, total nucleic acid extracted from amniotic fluid specimens was subjected to sequence-independent DNA and RNA amplification (SIA), which provides an unbiased representation of RNA viruses and, to a lesser degree, DNA viruses. Likewise, water reagent negative controls and buffer extraction negative controls (PBS subjected to the same sample processing and nucleic acid extraction protocols as samples) were included in these experiments. Only one amniotic fluid specimen yielded a eukaryotic virus-GB virus $C$ (specimen \#10, 12 viral sequencing reads). $G B$ virus $C$, also known as human pegivirus, is an RNA virus that is detected in approximately $2-4 \%$ of blood donors [35].

Because we only identified a single RNA virus, we then used multiple displacement amplification (MDA) which only identifies DNA viruses and is generally more sensitive for their detection than the SIA method [34]. The average number of viral sequencing reads in amniotic fluid was 331 reads (SD 248) (Fig. 3a). In comparison, stool specimens yielded an average of 34,027 viral sequencing reads (SD 44,667). The viral richness of amniotic fluid specimens was less than buffer extraction negative controls, water reagent negative controls, and stool samples (Fig. 3b) Additional file 5. Most of the viruses detected in amniotic fluid could be attributed to the extraction negative controls and/or water reagent negative controls (Fig. 3c).
We next sought to identify viruses that were detected only in amniotic fluid specimens, but absent from controls. We found that one amniotic fluid specimen (specimen 5) had 106 sequencing reads of a bacteriophage most similar to the Aeromonas phage 44RR2.8t. However, most other amniotic fluid specimens did not have "amniotic fluid unique" viral sequences (Fig. 3d). To evaluate whether inhibitors of PCR might be present in these amniotic fluid specimens, we performed a spike-in experiment. $1.8 \times 10^{7}$ copies of a plasmid containing a portion of the adenovirus hexon gene were added to an amniotic fluid specimen, followed by total nucleic acid extraction. Quantitative PCR targeting the spiked nucleic acid detected $3.3 \times 10^{6}$ copies (Fig. 3e), indicating that the paucity of viruses in amniotic fluid was not due to PCR inhibition.

\section{Discussion}

These data fail to identify a population of bacterial microbiota in amniotic fluid from healthy term pregnancies that meaningfully differs in concentration or content from the sequences amplified from negative controls (Figs. 1 and 2). The most parsimonious explanation for our inability to find differences is that amniotic fluid of healthy term pregnancies has negligible bacterial biomass. Similarly, we find only limited evidence for viral presence using metagenomic sequencing of material that has been subjected to preparation techniques optimized to recover DNA as well as RNA viruses, including DNA and RNA bacteriophages. Based on these analyses, we provisionally conclude that the term infant is not normally exposed to bacterial or viral populations in the immediate pre-birth interval.

Although the womb is traditionally viewed as sterile, recent molecular findings of bacterial DNA in the in utero environment challenge this paradigm $[16,22$, 36]. Since the intra-amniotic cavity is distinct from the placenta, we cannot discount the possibility that the placenta is separately colonized with microbes and that perhaps protective mechanisms prevent entry of these agents into the amniotic fluid. We also acknowledge that our data pertain only to amniotic fluid at term and that there might have been earlier in gestation colonization with bacteria and/or viruses. Indeed, alteration of the placental and amniotic fluid bacterial microbiota has been associated with preterm birth [12, 20, 37, 38]. Our work further demonstrates that when sequencing samples with low microbial density, it is critical to pay assiduous attention to controls, so as not to attribute microbial presence in specimens to contamination [25]. Our findings also prompt intensive efforts to learn how the chorioamniotic unit is so efficient at preventing colonization of the amniotic fluid despite evidence for circulating bacteria and viruses in healthy adults [39-41]. 
a

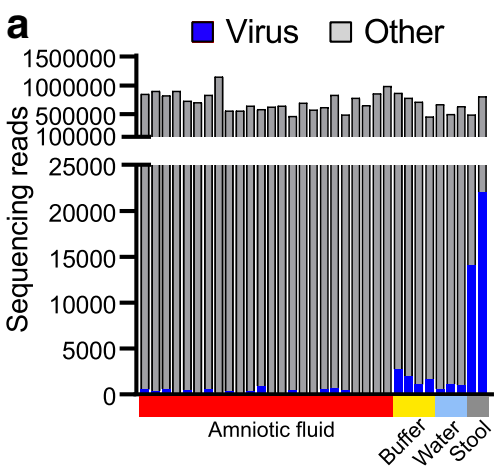

C

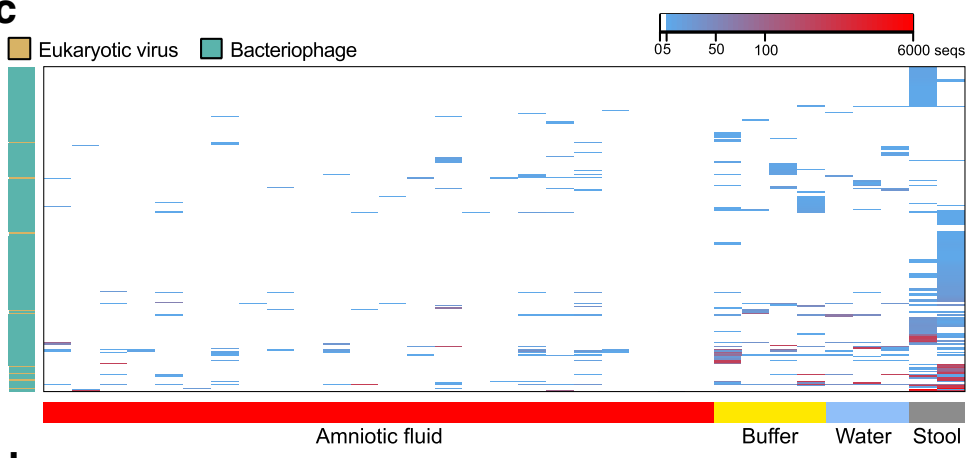

d

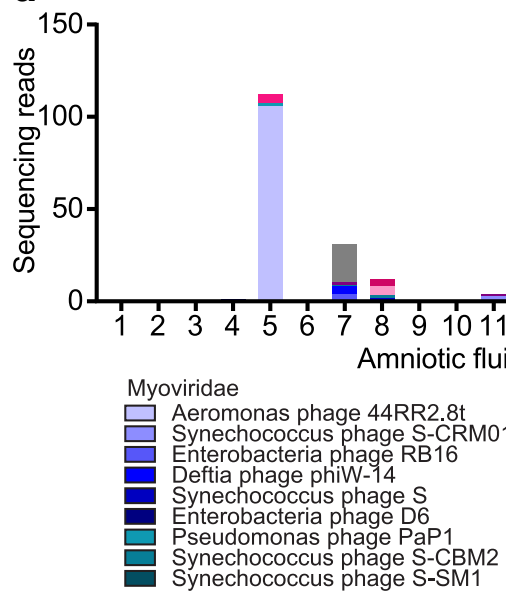

e

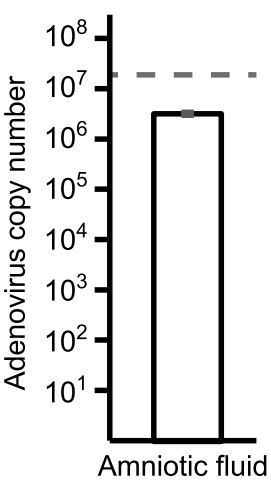

b

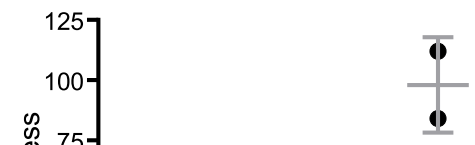

兽

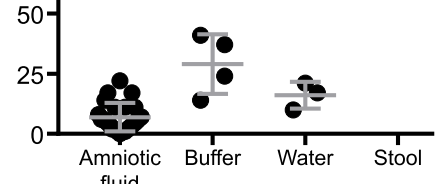

fluid 


\section{Methods}

\section{Subjects}

This study was approved by the Human Research Protection Office of Washington University School of Medicine in St. Louis. Twenty-four archived frozen amniotic fluid samples were obtained from the Women and Infants Health Specimen Consortium biobank at Washington University. Samples were selected if non-laboring, $\mathrm{C}$-section, and full-term gestation. Women with diabetes of any type, hypertension of any type, seizure disorder, intrauterine growth restriction, cancer, heart disease, kidney disease, or treated with acyclovir were excluded.

\section{Sample collection}

Amniotic fluids were obtained in a sterile fashion at the time of $\mathrm{C}$-section by aspirating through intact amniotic membranes. The amniotic fluid was then spun at $1620 \mathrm{~g}$ for $5 \mathrm{~min}$ at $4{ }^{\circ} \mathrm{C}$. Fluid was then placed into conical tubes and stored at $-80{ }^{\circ} \mathrm{C}$.

\section{Bacterial 16S rRNA gene sequencing}

One thousand fifty microliters of amniotic fluid was centrifuged (7000g, $10 \mathrm{~min}$ ). Extraction buffer was added to the pellet, which was disrupted by bead beating, and DNA was extracted using QIAamp DNA stool Mini Kit in a decontaminated sterile environment. In parallel, four buffer-only blank controls and four pediatric stool samples were disrupted by bead beating and extracted to serve as negative and positive controls respectively. PCR was performed using Golay-barcoded primers specific for the V4 region (F515/R806). Reactions were held at $94{ }^{\circ} \mathrm{C}$ for $2 \mathrm{~min}$ to denature the DNA, with amplification proceeding for $40 \mathrm{cy}$ cles at $94{ }^{\circ} \mathrm{C}$ for $15 \mathrm{~s}, 50{ }^{\circ} \mathrm{C}$ for $30 \mathrm{~s}$, and $68{ }^{\circ} \mathrm{C}$ for $30 \mathrm{~s}$, and a final extension of $2 \mathrm{~min}$ at $68^{\circ} \mathrm{C}$. Each sample was amplified in triplicate, combined, and cleaned using Ampure bead clean up kit. Equimolar libraries were pooled and sequenced using an Illumina MiSeq sequencer $(2 \times$ 250 v2 kit) at the Center for Genome Sciences \& Systems Biology at Washington University.

\section{Bacterial 16S rRNA gene analysis}

16S OTU clustering was performed using UPARSE (http://drive5.com/uparse/) [42]. Paired reads were merged and filtered at maximum expected error threshold of 1.0 (-fastq_maxee 1.0). Unique sequences were identified using the "fastx_uniques" command, followed by clustering at $97 \%$ and chimera filtering using "cluster_otus". For OTU identification, the 16S rRNA gene sequences were subjected to BLASTN search against the NCBI $16 \mathrm{~S}$ ribosomal RNA database. Ecological analyses were performed using the vegan package in $\mathrm{R}$ and QIIME2 scripts.
Bacterial 16S rRNA gene qPCR

SYBR green quantitative PCR for $16 \mathrm{~S}$ rRNA gene was performed using primers 515F (5'-GTGCCAGCM GCCGCGGTAA-3') and 805R (5'-GACTACCAGGGTATCTAATCC- $3^{\prime}$ ) primers on DNA as previously described [43]. The qPCR was performed using TaqMan Fast Advanced Master Mix (Thermo Fisher). The 25- $\mu \mathrm{L}$ reaction included $5 \mu \mathrm{L}$ of extracted DNA and $5 \mu \mathrm{mol}$ of each primer. The following cycling conditions were used: $95{ }^{\circ} \mathrm{C}$ for $10 \mathrm{~min}$, then 40 cycles of $95{ }^{\circ} \mathrm{C}$ for $15 \mathrm{~s}$ and $60{ }^{\circ} \mathrm{C}$ for $60 \mathrm{~s}$ followed by a melt curve. To generate a standard curve for this assay, a plasmid containing the 16S PCR amplicon from Escherichia coli (DH5 $\alpha$ ) was serially diluted from $5 \times 10^{7}$ copies to five copies and used to generate a standard curve; a limit of detection of 500 copies was defined. Samples were tested in a 96-well plate format with six water-only negative controls, six buffer only controls, and 14 pediatric stools samples. All water controls were below the limit of detection.

\section{Virome sequencing}

One thousand fifty microliters of amniotic fluid was centrifuged $(7000 \mathrm{~g}, 10 \mathrm{~min})$. The supernatant was then filtered through a $0.45-\mu \mathrm{m}$ membrane. Total nucleic acid was extracted from the filtrate using COBAS Ampliprep (Roche). In parallel, PBS was filtered and extracted to serve as extraction reagent-only control and two pediatric stool samples were filtered and extracted to serve as a positive control. Sequence-independent DNA and RNA amplification (SIA) was performed on the total nucleic acid as previously described [34] and used for NEBNext library construction (Illumina). For multiple displacement amplification (MDA), total nucleic acid and three water negative controls were amplified with Phi29 polymerase (GenomiPhi V2 kit, GE Healthcare) according to the manufacturer's instructions and used for Nextera DNA library construction (Illumina). Libraries were purified and size-selected using Agencourt Ampure XP beads (Beckman-Coulter), followed by quantification using a 2100 Bioanalyzer (Agilent Technologies). Multiplexed SIA libraries were pooled and sequenced separately from multiplexed MDA libraries.

\section{Virome sequence analysis}

Illumina sequencing reads were analyzed using VirusSeeker [44], a BLAST-based computational pipeline to identify viral sequences. Taxonomic classification for bacteriophage sequences were parsed using MEGAN version 6.10.2 [45]. Ecological analyses were performed using the vegan package in $\mathrm{R}$ and QIIME2 scripts. Sequencing reads were normalized to 400,000 reads per sample. 


\section{Spiking of amniotic fluid}

To determine whether inhibitors of PCR might be present in these amniotic fluid specimens, $1.8 \times 10^{7}$ copies of a plasmid containing a portion of the adenovirus hexon gene were added to $1050 \mu \mathrm{L}$ of amniotic fluid and to $1050 \mu \mathrm{L}$ of PBS. Total nucleic acid was extracted from these spiked samples using COBAS Ampliprep (Roche). A previously published qPCR targeting the adenovirus hexon gene was then used to quantify the spiked DNA [46]. The qPCR was performed using TaqMan Fast Advanced Master Mix (Thermo Fisher). The $20-\mu \mathrm{L}$ reaction included $5 \mu \mathrm{L}$ of extracted total nucleic acid, 18 pmol of each primer, and 5 pmol of probe. The following cycling conditions were used: $95{ }^{\circ} \mathrm{C}$ for $2 \mathrm{~min}$, then 45 cycles of $95{ }^{\circ} \mathrm{C}$ for $1 \mathrm{~s}$ and $60^{\circ} \mathrm{C}$ for $20 \mathrm{~s}$. To generate a standard curve for this assay, a plasmid containing the region of interest was used in serial dilutions from $5 \times 10^{6}$ copies to five copies and a limit of detection of five copies was defined. Samples were tested triplicate in a 96-well plate format with wateronly negative controls. All water controls were below the limit of detection.

\section{Statistics}

To compare the 16S rRNA gene copy number between specimens, CT values from qPCR assay were converted to copy numbers as determined by the standard curve $\left[y=-4.4358 x+41.126, R^{2}=0.9941\right]$. Copy number was normalized to input volume, and a non-parametric Mann-Whitney test (two-tailed) was performed to compare the 16S rRNA gene copy number between specimen types. The bacterial OTU richness was rarefied from 10,000 to 50,000 sequencing reads, in steps of 10,000 over 10 iterations each. To compare the bacterial microbiota beta diversity between specimen groups, Mann-Whitney test (two-tailed) was performed. The heatmap of virome abundance was plotted in $\mathrm{R}$ using gplots, with clustering by virus abundance (rows).

\section{Additional files}

Additional file 1: Table S1. Summary of demographics (DOCX $13 \mathrm{~kb}$ )

Additional file 2: Metadata associated with all samples used in this study. (TXT $1 \mathrm{~kb}$ )

Additional file 3: $16 \mathrm{~S}$ operational taxonomic unit table. (CSV $40 \mathrm{~kb}$ )

Additional file 4: Fasta sequence file of most abundant OTUs only detected in amniotic fluid. (FA $5 \mathrm{~kb}$ )

Additional file 5: Virome species table. (CSV $73 \mathrm{~kb}$ )

\section{Abbreviations}

CMV: Cytomegalovirus; HPV: Human papilloma viruses; MDA: Multiple displacement amplification; SIA: Sequence-independent DNA and RNA amplification

\section{Acknowledgements}

We thank Dr. David Wang for the discussion and feedback.

\section{Funding}

This work was supported in part by the Children's Discovery Institute (MD-FR-2013-292), Doris Duke Charitable Foundation (2017076), March of Dimes (BOC 388999), the Women and Infant Health Consortium program at Washington University which is supported in part by the Washington University Institute of Clinical and Translational Sciences by the NIH/National Center for Advancing Translational Sciences (NCATS), CTSA grant

UL1TR000448, NIH grant R00 DK107923, and Arizona State University startup funding (ESL).

\section{Availability of data and materials}

Sequence data has been deposited to the NCBI Sequence Read Archive under BioProject accession number SRP128680.

\section{Authors' contributions \\ $\mathrm{LRH}$ and ESL conceived and designed the experiments, analyzed the data, and wrote the manuscript. CR and ESL performed the experiments. All authors read and approved the final manuscript.}

\section{Ethics approval and consent to participate}

The institutional review board at Washington University School of Medicine approved the study. Subjects provided informed consent to be included in the Women and Infants Health Specimen Consortium biobank at

Washington University.

\section{Competing interests}

The authors declare that they have no competing interests.

\section{Publisher's Note}

Springer Nature remains neutral with regard to jurisdictional claims in published maps and institutional affiliations.

\section{Author details}

${ }^{1}$ School of Life Sciences, Arizona State University, Tempe, AZ 85287, USA. ${ }^{2}$ Center for Fundamental and Applied Microbiomics, The Biodesign Institute, Tempe, AZ 85287, USA. ${ }^{3}$ Department of Pediatrics, Washington University School of Medicine, 660 S. Euclid Ave., Campus Box 8208, St. Louis, MO 63110, USA.

Received: 16 February 2018 Accepted: 6 May 2018

Published online: 11 May 2018

\section{References}

1. Lim ES, Wang D, Holtz LR. The bacterial microbiome and virome milestones of infant development. Trends Microbiol. 2016;24:801-10.

2. Prevedourakis CN, Strigou-Charalabis E, Kaskarelis DB. Bacterial invasion of amniotic cavity during pregnancy and labor. Obstet Gynecol. 1971; 37:459-61.

3. Fernandez $\mathrm{H}$, Montuclard B, Guibert M. Does intraamniotic infection in the early phase of the second trimester really exist? Am J Obstet Gynecol. 1996; 175:1077-8.

4. Gervasi MT, Romero R, Bracalente G, Erez O, Dong Z, Hassan SS, Yeo L, Yoon $\mathrm{BH}$, Chaiworapongsa T. Midtrimester amniotic fluid concentrations of interleukin-6 and interferon-gamma-inducible protein-10: evidence for heterogeneity of intra-amniotic inflammation and associations with spontaneous early (<32 weeks) and late (>32 weeks) preterm delivery. J Perinat Med. 2012;40:329-43.

5. Cherouny PH, Pankuch GA, Botti JJ. Occult intraamniotic infection at the time of midtrimester genetic amniocentesis: a reassessment. Infect Dis Obstet Gynecol. 1994;2:136-9.

6. Goldstein I, Zimmer EZ, Merzbach D, Peretz BA, Paldi E. Intraamniotic infection in the very early phase of the second trimester. Am J Obstet Gynecol. 1990;163:1261-3.

7. Berg TG, Philpot KL, Welsh MS, Sanger WG, Smith CV. Ureaplasma/ mycoplasma-infected amniotic fluid: pregnancy outcome in treated and nontreated patients. J Perinatol. 1999;19:275-7.

8. Mandar R, Li K, Ehrenberg A, Smidt I, Raukas E, Kask V, Mikelsaar M. Amniotic fluid microflora in asymptomatic women at mid-gestation. Scand J Infect Dis. 2001;33:60-2. 
9. Rowlands S, Danielewski JA, Tabrizi SN, Walker SP, Garland SM. Microbial invasion of the amniotic cavity in midtrimester pregnancies using molecular microbiology. Am J Obstet Gynecol. 2017;217:71 e71-5.

10. Gerber S, Vial Y, Hohlfeld P, Witkin SS. Detection of Ureaplasma urealyticum in second-trimester amniotic fluid by polymerase chain reaction correlates with subsequent preterm labor and delivery. J Infect Dis. 2003;187:518-21.

11. Nguyen DP, Gerber S, Hohlfeld P, Sandrine G, Witkin SS. Mycoplasma hominis in mid-trimester amniotic fluid: relation to pregnancy outcome. J Perinat Med. 2004;32:323-6.

12. DiGiulio DB, Romero R, Amogan HP, Kusanovic JP, Bik EM, Gotsch F, Kim CJ, Erez O, Edwin S, Relman DA. Microbial prevalence, diversity and abundance in amniotic fluid during preterm labor: a molecular and culture-based investigation. PLoS One. 2008;3:e3056.

13. DiGiulio DB, Gervasi M, Romero R, Mazaki-Tovi S, Vaisbuch E, Kusanovic JP, Seok KS, Gomez R, Mittal P, Gotsch F, et al. Microbial invasion of the amniotic cavity in preeclampsia as assessed by cultivation and sequencebased methods. J Perinat Med. 2010;38:503-13.

14. DiGiulio DB, Gervasi MT, Romero R, Vaisbuch E, Mazaki-Tovi S, Kusanovic JP, Seok KS, Gomez R, Mittal P, Gotsch F, et al. Microbial invasion of the amniotic cavity in pregnancies with small-for-gestational-age fetuses. J Perinat Med. 2010;38:495-502.

15. DiGiulio DB, Romero R, Kusanovic JP, Gomez R, Kim CJ, Seok KS, Gotsch F, Mazaki-Tovi S, Vaisbuch E, Sanders K, et al. Prevalence and diversity of microbes in the amniotic fluid, the fetal inflammatory response, and pregnancy outcome in women with preterm pre-labor rupture of membranes. Am J Reprod Immunol. 2010;64:38-57.

16. Collado MC, Rautava S, Aakko J, Isolauri E, Salminen S. Human gut colonisation may be initiated in utero by distinct microbial communities in the placenta and amniotic fluid. Sci Rep. 2016;6:23129.

17. Perez-Munoz ME, Arrieta MC, Ramer-Tait AE, Walter J. A critical assessment of the "sterile womb" and "in utero colonization" hypotheses: implications for research on the pioneer infant microbiome. Microbiome. 2017:5:48.

18. Willyard C. Could baby's first bacteria take root before birth? Nature. 2018; 553:264-6.

19. Hillier SL, Martius J, Krohn M, Kiviat N, Holmes KK, Eschenbach DA. A casecontrol study of chorioamnionic infection and histologic chorioamnionitis in prematurity. N Engl J Med. 1988;319:972-8.

20. Stout MJ, Conlon B, Landeau M, Lee I, Bower C, Zhao Q, Roehl KA, Nelson DM, Macones GA, Mysorekar IU. Identification of intracellular bacteria in the basal plate of the human placenta in term and preterm gestations. Am J Obstet Gynecol. 2013;208:226 e221-7.

21. Jimenez E, Fernandez L, Marin ML, Martin R, Odriozola JM, Nueno-Palop C, Narbad A, Olivares M, Xaus J, Rodriguez JM. Isolation of commensal bacteria from umbilical cord blood of healthy neonates born by cesarean section. Curr Microbiol. 2005;51:270-4.

22. Aagaard K, Ma J, Antony KM, Ganu R, Petrosino J, Versalovic J. The placenta harbors a unique microbiome. Sci Transl Med. 2014;6:237ra265.

23. Hu J, Nomura Y, Bashir A, Fernandez-Hernandez H, Itzkowitz S, Pei Z, Stone $J$, Loudon $\mathrm{H}$, Peter I. Diversified microbiota of meconium is affected by maternal diabetes status. PLoS One. 2013;8:e78257.

24. Gosalbes MJ, Llop S, Valles Y, Moya A, Ballester F, Francino MP. Meconium microbiota types dominated by lactic acid or enteric bacteria are differentially associated with maternal eczema and respiratory problems in infants. Clin Exp Allergy. 2013;43:198-211.

25. Lauder AP, Roche AM, Sherrill-Mix S, Bailey A, Laughlin AL, Bittinger $K$, Leite R, Elovitz MA, Parry S, Bushman FD. Comparison of placenta samples with contamination controls does not provide evidence for a distinct placenta microbiota. Microbiome. 2016;4:29.

26. Wenstrom KD, Andrews WW, Bowles NE, Towbin JA, Hauth JC, Goldenberg RL. Intrauterine viral infection at the time of second trimester genetic amniocentesis. Obstet Gynecol. 1998;92:420-4.

27. Baschat AA, Towbin J, Bowles NE, Harman CR, Weiner CP. Prevalence of viral DNA in amniotic fluid of low-risk pregnancies in the second trimester. J Matern Fetal Neonatal Med. 2003;13:381-4.

28. Gervasi MT, Romero R, Bracalente G, Chaiworapongsa T, Erez O, Dong Z, Hassan SS, Yeo L, Yoon BH, Mor G, et al. Viral invasion of the amniotic cavity (VIAC) in the midtrimester of pregnancy. J Matern Fetal Neonatal Med. 2012; 25:2002-13.

29. Van den Veyver IB, Ni J, Bowles N, Carpenter RJ Jr, Weiner CP, Yankowitz J, Moise KJ Jr, Henderson J, Towbin JA. Detection of intrauterine viral infection using the polymerase chain reaction. Mol Genet Metab. 1998;63:85-95.
30. Reddy UM, Baschat AA, Zlatnik MG, Towbin JA, Harman CR, Weiner CP. Detection of viral deoxyribonucleic acid in amniotic fluid: association with fetal malformation and pregnancy abnormalities. Fetal Diagn Ther. 2005;20:203-7.

31. Romero R, Miranda J, Chaiworapongsa T, Chaemsaithong P, Gotsch F, Dong Z, Ahmed Al, Yoon BH, Hassan SS, Kim CJ, et al. A novel molecular microbiologic technique for the rapid diagnosis of microbial invasion of the amniotic cavity and intra-amniotic infection in preterm labor with intact membranes. Am J Reprod Immunol. 2014;71:330-58.

32. Romero R, Miranda J, Chaemsaithong P, Chaiworapongsa T, Kusanovic JP, Dong Z, Ahmed Al, Shaman M, Lannaman K, Yoon BH, et al. Sterile and microbial-associated intra-amniotic inflammation in preterm prelabor rupture of membranes. J Matern Fetal Neonatal Med. 2015;28:1394-409.

33. Roberto Romero, Jezid Miranda, Tinnakorn Chaiworapongsa, Piya Chaemsaithong, Francesca Gotsch, Zhong Dong, Ahmed I. Ahmed, Bo Hyun Yoon, Sonia S. Hassan, Chong J. Kim, Steven J. Korzeniewski, Lami Yeo, Yeon Mee Kim. Sterile intra-amniotic inflammation in asymptomatic patients with a sonographic short cervix: prevalence and clinical significance. J Matern Fetal Neonatal Med. 2014;28(11):1343-1359. doi: https://doi.org/10.3109/ 14767058.2014.954243.

34. Lim ES, Zhou Y, Zhao G, Bauer IK, Droit L, Ndao IM, Warner BB, Tarr PI, Wang $D$, Holtz LR. Early life dynamics of the human gut virome and bacterial microbiome in infants. Nat Med. 2015;21:1228-34.

35. Stapleton JT, Foung S, Muerhoff AS, Bukh J, Simmonds P. The GB viruses: a review and proposed classification of GBV-A, GBV-C (HGV), and GBV-D in genus Pegivirus within the family Flaviviridae. J Gen Virol. 2011;92:233-46.

36. Parnell LA, Briggs CM, Cao B, Delannoy-Bruno O, Schrieffer AE, Mysorekar IU. Microbial communities in placentas from term normal pregnancy exhibit spatially variable profiles. Sci Rep. 2017;7:11200.

37. Prince AL, Ma J, Kannan PS, Alvarez M, Gisslen T, Harris RA, Sweeney EL, Knox CL, Lambers DS, Jobe AH, et al. The placental membrane microbiome is altered among subjects with spontaneous preterm birth with and without chorioamnionitis. Am J Obstet Gynecol. 2016;214:627 e621-16.

38. Doyle RM, Alber DG, Jones HE, Harris K, Fitzgerald F, Peebles D, Klein N. Term and preterm labour are associated with distinct microbial community structures in placental membranes which are independent of mode of delivery. Placenta. 2014;35:1099-101.

39. Breitbart M, Rohwer F. Method for discovering novel DNA viruses in blood using viral particle selection and shotgun sequencing. BioTechniques. 2005; 39:729-36.

40. Moustafa A, Xie C, Kirkness E, Biggs W, Wong E, Turpaz Y, Bloom K, Delwart E, Nelson KE, Venter JC, Telenti A. The blood DNA virome in 8,000 humans. PLoS Pathog. 2017;13:e1006292.

41. Parahitiyawa NB, Jin LJ, Leung WK, Yam WC, Samaranayake LP. Microbiology of odontogenic bacteremia: beyond endocarditis. Clin Microbiol Rev. 2009; 22:46-64. Table of Contents

42. Edgar RC. UPARSE: highly accurate OTU sequences from microbial amplicon reads. Nat Methods. 2013;10:996-8.

43. Baldridge MT, Nice TJ, McCune BT, Yokoyama CC, Kambal A, Wheadon M, Diamond MS, Ivanova Y, Artyomov M, Virgin HW. Commensal microbes and interferon-lambda determine persistence of enteric murine norovirus infection. Science. 2015;347:266-9.

44. Zhao G, Wu G, Lim ES, Droit L, Krishnamurthy S, Barouch DH, Virgin HW, Wang D. VirusSeeker, a computational pipeline for virus discovery and virome composition analysis. Virology. 2017;503:21-30.

45. Huson DH, Beier S, Flade I, Gorska A, El-Hadidi M, Mitra S, Ruscheweyh HJ, Tappu R. MEGAN Community Edition-interactive exploration and analysis of large-scale microbiome sequencing data. PLoS Comput Biol. 2016;12: e1004957.

46. Jothikumar N, Cromeans TL, Hill VR, Lu X, Sobsey MD, Erdman DD. Quantitative real-time $P C R$ assays for detection of human adenoviruses and identification of serotypes 40 and 41. Appl Environ Microbiol. 2005:71:3131-6. 